\title{
A quantitative approach for identifying plant ecogroups in the Romanian Early Jurassic
} terrestrial vegetation

(1)

Maria Barbacka ${ }^{1 *}$, Mihai Emilian Popa ${ }^{2}$, Józef Mitka $^{3}$, Emese Bodor $^{4}$, Zoltán Püspöki ${ }^{5}$,

Richard William McIntosh ${ }^{6}$

${ }^{1 *}$ Corresponding author; Hungarian Natural History Museum, Department of Botany, H-1476 Budapest, Pf. 222, Hungary; W. Szafer Institute of Botany, Polish Academy of Sciences, Lubicz 46, 31-512 Kraków, Poland; e-mail: barbacka@bot.nhmus.hu;

${ }^{2}$ University of Bucharest, Faculty of Geology and Geophysics, Laboratory of Palaeontology, 1, N. Bălcescu Ave., 010041, Bucharest, Romania; e-mail: mihai@mepopa.com; ${ }^{3}$ Jagiellonian University in Kraków, Botanical Garden, Kopernika 27, 31-501 Kraków, Poland; e-mail: j.mitka@uj.edu.pl;

${ }^{4}$ Geological and Geophysical Institute of Hungary, Geological and Geophysical Collections, 1143 Budapest, Stefánia út 14, Hungary; Eötvös Loránd University, Department of Palaeontology, 1117 Budapest, Pázmány Péter sétány 1/C, Hungary; e-mail: emesebodor@gmail.com.

${ }^{5}$ Geological and Geophysical Institute of Hungary, Department of Data Management, 1145 Budapest, Columbus u. 17-23., Hungary, e-mail: puspoki.zoltan@mfgi.hu ${ }^{6}$ University of Debrecen, Department of Mineralogy and Geology, 4032 Debrecen, Egyetem tér 1., e-mail: mcintosh.richard@science.unideb.hu

\section{Abstract}

Community level ecology is considered to support significantly the recognition of the ecological status of plant taxa and the identification of plant ecogroups, thus it generally 
provides extended data sets on the spatial and temporal changes of ecological factors. Since research based exclusively on plant structure and their supposed adaptation to the environment is now considered inadequate, statistical methods can be used. Assuming that cooccurrence of plant fossils on a single hand specimen in the case of autochthonous or paraautochthonous floras is the result of their growth in the same phytocenosis, quantitative ecological analysis on Mesozoic materials would yield significant insights. In this paper statistical and multivariate quantitative analyses of Early Jurassic plant fossil records from the Steierdorf Formation in Anina (South Carpathians, Romania) are presented. Four palaeoecological groups of taxa were distinguished by Principal Component Analysis (PCA) and interpreted as plant assemblages of various palaeobiotopes associated with the sedimentary facies of the enclosing formation. A group of samples was analyzed using the Principal Coordinate (PCO) method and the statistical significance (p \{less than or equal to $\}$ $0.05)(\mathrm{p} \leq 0.05)$ of individual binary responses of taxa along the first two PCO ordination axes was tested by General Linear Model (GLM). They revealed putative palaeoecological gradients: axis 1 - disturbance caused by water level fluctuations, axis 2 - temperature, corresponding with the already assumed environmental and climatic change at the Hettangian/Sinemurian boundary. Multivariate analyses enabled the identification of palaeoecological groups and thus inferring palaeogeographical conditions based on Mesozoic materials.

Keywords: Palaeoecology; plant ecogroups; Principle Component Analysis; multivariate analysis; Jurassic; Romania 


\section{Introduction}

Apart from the classical interpretation (Thorn, 2001; van Konijnenburg-van Cittert, 2002; Wang, 2002; Gordenko, 2008; Kustatscher et al., 2010) of fossil plant structures as a reaction to changing palaeoecological conditions, co-occurrence of taxa in the case of autochthonous or paraautochthonous floras can be very informative.

Numerous palaeoecological reconstructions were based on different proxies like evidence of fossil palynomorphs (e. g. Abbink, 1998; Abbink et al., 2001, 2004; Bonis et al., 2010) and megaflora (e. g. Spicer \& Hill, 1979; Spicer \& Parrish, 1990; Spicer et al., 1992; Thorn, 2001; Spicer et al., 2002; Bercovici et al., 2009; Barbacka, 2011). Also complex geological data can be used like palaeosols (Sheldon \& Tabor, 2009; Botfalvai et al., 2016), peat forming environments (Phillips \& Peppers, 1984; DiMichele \& Phillips, 1994; Gastaldo et al., 2004; Hámor-Vidó, 2004; DiMichele et al., 2007), complex sedimentology, palaeozoological and palaeobotanical data (DiMichele \& Beall, 1990; DiMichele et al., 2008; Falcon-Lang et al., 2009; Libertin et al., 2009; Barbacka et al., 2015). Furthermore, analytical methods were used in palaeovegetational reconstructions e.g. basic statistical methods like cooccurrences, diversity (McElwain et al., 2007; Pálfy \& Kocsis, 2014) and multivariate methods (Spicer \& Hill, 1979; Barbacka, 2011; Barbacka et al., 2015).

Assuming that co-occurrence of plant fossils on the same hand specimen is the result of their growth in the same phytocenosis (Wing \& DiMichele, 1995) plant ecogroups can be distinguished, and the range of environmental tolerance of individual taxa can be determined. Thus, with a verified multivariate statistical method at hand, the quantitative community level ecological approach could have an impact on the interpretation of the response of plants to environmental changes in the past, and this has been the subject of increased interest recently (DiMichele \& Gastaldo, 2008). 
The first such study focusing on Early Jurassic flora from the Mecsek Mountains, South Hungary dominated by paralic environments, identified five ecogroups containing taxa that changed in accordance with moisture and disturbance (Barbacka, 2011). In the current study, we test a multivariate statistical method for Romanian Early Jurassic deposits in Anina in order to extend the palaeoecological hypothesis and improve the effectiveness of the approach. Besides other methods PCA was performed in the community level ecological study of Spicer \& Hill (1979) related to the Middle Jurassic of Yorkshire, however, they sampled the investigated plant bed quantitatively.

The ecological gradients in Anina linked with the ordination axes were inferred indirectly and based on plant morphology/ecological profile as well as sedimentary data (Popa, 1998). Thus, they were heuristic working hypotheses that were supported by plant joint occurrences and proxy data to support conclusions.

\section{Geological and palaeobotanical background}

The Reşiţa Basin, also known in the geological literature as the Reşiţa-Moldova Nouă sedimentary zone, is a major sedimentary basin of the Getic Nappe in the South Carpathians, Romania (Fig. 1). It is composed of Palaeozoic (Upper Carboniferous and Lower Permian) and Mesozoic terrestrial formations (Lower Jurassic, Hettangian - Sinemurian in age) which yield fossil flora and fauna (Popa, 2009). The Lower Jurassic terrestrial sequence of this basin is assigned to the Steierdorf Formation (Bucur, 1991, 1997; Popa \& Kędzior, 2008; Kędzior \& Popa, 2013), a coal bearing formation which includes eight coal seams exploited through extensive underground mining works since 1792 in Anina (formerly known as Steierdorf), Caraş-Severin County (Fig. 2). The coal mining complex was one of the largest in Europe, as it encompassed several coalfields (Anina North, Zona Nouă, Brădet, Uteriş, Kübeck, etc.), a high number of pits (Pits I, II, IV, David, etc.), blind pits (underground shafts), and open cast 
mines (quarries) such as Ponor, Colonia Cehă and Hildegard (Popa, 2009). This coal mining complex was closed in 2006, and it included at the time $42 \mathrm{~km}$ of active galleries reaching a depth of $1300 \mathrm{~m}$, making Anina one of the deepest coal mines in Europe at the time. A high number of sterile dumps fill various valleys in the Anina area, and they are also very rich in fossils. Today, Ponor and Colonia Cehă Quarries and Pit I (Schlucht) in Anina are considered Sites of Special Scientific Interest (SSSIs) for their rich and well preserved fossil content. The extensive underground coal mining works in Anina followed the local, complicated geological structures represented by various synclines (in Brădet Coalfield) and anticlines (in Anina and Zona Nouă Coalfields) through directional and transversal galleries, blind pits and extraction chambers. Such extensive works permitted unique sampling of fossil plants, with three dimensional control of stratigraphic and lateral distribution of the palaeoflora within the Steierdorf Formation. Such exceptional conditions for precise fossil sampling enabled one of the authors (MEP) to build a large collection of fossil plants during 16 years of continuous geological activity in the mining complex of Anina area, between 1990 and 2006 (Popa, 2009, 2011). These fossils were collected along all types of underground works in Anina area, especially from extraction chambers and from directional galleries, within the roof shales, from the base of coal seams, as well as from all stratigraphic intervals between coal seams. Detailed fossil sampling, sedimentological and petrographical studies in underground mining works made it possible to clarify the precise stratigraphic succession of the Hettangian - Sinemurian palaeoflora of the Steierdorf Formation (Popa, 1992, 2000b) and enabled the identification of the stratigraphic level of samples collected from sterile dumps or of hand specimens studied in historical collections curated in Bucharest, Cluj-Napoca, Timişoara, Budapest, Vienna, etc. (Popa, 1992, 2000b, 2009; Popa \& Meller, 2009). To the underground fossils was added material collected from open-cast mines, road cuts, natural outcrops and sterile dumps (Popa, 2009) in Anina area. 
As shown in Fig. 2 the Steierdorf Formation includes two members, the Dealul Budinic Member, Lower to Middle Hettangian in age, and the Valea Tereziei Member, Upper

Hettangian - Sinemurian in age (Bucur, 1991, 1997; Popa \& Kędzior, 2008). The Steierdorf Formation unconformably overlays the Lower Permian Ciudanoviţa Formation (red beds), and it is conformably overlain by the Pliensbachian - Middle Toarcian Uteriş Formation (black shales). The Dealul Budinic Member is a coarser, basal sedimentary unit dominated by conglomerates and micro-conglomerates, indicating alluvial fan depositional environments. The Valea Tereziei Member is dominated by sandstones, clays, fireclays and coal seams, indicating fluviatile, flood plain, crevasse splay and lacustrine depositional environments, with mire (coal generating swamp or marsh) episodes. The conglomerates and microconglomerates of the Valea Tereziei Member are included in channel fill successions, as parts of a large braided river complex (Kędzior \& Popa, 2013). The eight coal seams are composed of bituminous, coking coals, with thicknesses reaching $2.5 \mathrm{~m}$ in the western flank of Anina Anticline. The Steierdorf Formation was generated in a mountainous depression, bordered by metamorphosed promontories of the Sebeş-Lotru Group or of Upper Palaeozoic formations. Between coal seams 4 and 5, a well developed lateral fireclay seam was identified, representing a large lacustrine system and a lithological marker which also coincides with the Hettangian - Sinemurian boundary within the Valea Tereziei Member (Popa, 2000a, b, Popa 2009; Kędzior \& Popa, 2013).

The Steierdorf Formation includes two separate floral assemblages, the Hettangian Thaumatopteris brauniana range Zone and the Sinemurian Nilssonia cf. orientalis acme Zone (Popa, 2000a, b; Popa \& van Konijnenburg-van Cittert, 2006), each with characteristic taxa. The boundary between the two floras as well as the Hettangian - Sinemurian boundary is represented by the fireclay seam. 

northern frame of the Tethys Ocean, on the southern part of the boreal (Eurosinian) continental mass (Pieńkowski et al., 2009). The climate was subtropical and monsoonal

152 proved by pseudo-annual rings observed in silicified woods from Holbav (near Braşov, central Romania). During the Hettangian and Sinemurian times below and above the fireclay level, the climate was subtropical, wet, monsoonal. The occurrence of Pterophyllum, Phoenicopsis, as well as sporadic Sphenobaiera and Czekanowskia (higher latitude groups, Siberian influences) suggest not very hot climate in the Hettangian. The presence of bennettitaleans like Zamites or Ptilophyllum, and other warm indicators imply hotter climate in the Sinemurian above the fireclay level up to the top of coal seam 8 .

The palaeoflora of the Steierdorf Formation in Anina is a key European Early Jurassic flora. It is typically compressive and coal generating (coal flora), and also highly diverse (the most representative taxa are shown in Fig. 3 a-e) and well preserved (Popa, 1998, 2000a, b, 2005, 2009, 2014; Popa \& van Konijnenburg-van Cittert, 2006), making Anina, together with its palaeozoological ichnospecies, a plant fossil Lagerstätte locality considering both diversity and conservation (Popa, 1997, 2014). The palaeoflora of Anina was studied since the 19th Century (Foetterle, 1850; Ettingshausen, 1852; Andrae, 1855), followed by modern studies of Semaka (1962), Givulescu (1998), Popa (1992, 1998, 2000a, b, 2009, 2014), Popa \& van Konijnenburg-van Cittert (2006) and Popa \& Meller (2009). It includes bryophytes (Hepaticae), pteridophytes (lycopsids, sphenopsids, filicopsids) and gymnosperms (pteridospermopsids, cycadaleans, bennettitaleans, ginkgopsids, coniferopsids), well preserved with abundant cuticles and in situ spores (Popa, 2000a, 2009; Popa \& van Konijnenburg-van Cittert, 1999). The microflora of the fireclay seam of the Valea Tereziei Member was studied by Antonescu (1973), and it records Early and Middle Jurassic palynomorphs. 

characterized by Popa $(1997,1998,2000 \mathrm{a}, 2009,2014)$ in relation to their depositional environments, with their age and with their coal generating character. These ecogroups were identified in the field at various stratigraphic levels, in roof shales or within sandstone and mudstone levels between coal seams, corresponding to mire, mire borders, levees and flood plain areas. The following assemblages were identified:

a. mire (marsh) dwellers, such as the sphenopsid Neocalamites (Schizoneura) carcinoides, which has a long stratigraphic range, crossing the Hettangian - Sinemurian boundary due to the persistence of its aquatic habitat and to the preservation of its ecological niche;

b. dwellers of mire borders in flooded areas, such as the pteridosperm Pachypteris speciosa or the conifer Podozamites paucinervis, often competing for their habitat, as this competition was reflected in the thickness of the coal seams generated (Popa, 1997b);

c. dry land dwellers, in areas of flood plains or levees, represented by ferns (Cladophlebis denticulata, Dictyophyllum nilssonii), cycadaleans (Nilssonia cf. orientalis, N. undulata), bennettitaleans (Zamites schmiedelii, Z. andraeanus) and ginkgoaleans (Ginkgoites marginatus).

d. possible upland flora representatives, such as the ginkgoal Phoenicopsis potoniei, that was considered a Siberian influence indicator by Givulescu (1998).

Regarding the coal generating processes, Popa (1997b, 1998, 2000a, 2014) considered mire dwellers such as sphenopsids and mire border dwellers such as pteridosperms and conifers as primary (main) coal generators. Drier land area dwellers (floodplains, levees) such as the association of ferns, bennettitaleans and ginkgoaleans were considered as secondary coal generators. This association enters the mire area in its final stages, while the marsh was being filled with sediments, therefore contributing to coal genesis and being continuously recorded in the roof shales, especially in the roof shales of coal seams 5-8 (Sinemurian) in Anina. The 
ternary assemblage of a fern, a bennettitalean and a ginkgoalean as secondary coal generators is considered by Popa (2014) as a rule for coal genesis and having a much wider occurrence in Europe and Greenland during Mesozoic times, although these taxa were not strictly mire or mire border dwellers but only opportunistic species.

\section{Material and methods}

\subsection{Sampling}

The studied material includes samples with at least two species occurring on the same surface of hand specimens. The material belongs to the M. E. Popa Collection, curated at the University of Bucharest, Faculty of Geology and Geophysics, Laboratory of Palaeontology and at the Geological Museum (Geological Institute of Romania) in Bucharest as well as to various historical collections (A. Semaka, I. Z. Barbu Collections) curated at the same institutions. Except for hand specimens of the M. E. Popa Collection, all other samples were collected previously from sterile dumps by several scientists. The stratigraphic position of the samples, however, was identified later, following a detailed sampling in the underground mining works in Anina revealing plant species ranges (Popa, 2000b). The samples considered for this study have a precise stratigraphic position within the Steierdorf Formation, their petrographical and sedimentological context is also well characterized (Popa, 2011), and they yield at least two plant fossils co-occurring on the same surface of the hand specimen. Most of these samples are associated with palaeosols level and with roof shales, indicating the in situ (autochthonous) character of the leaf material. The size of samples varies between 100$500 \mathrm{~mm}$ in length and width, while the plant fragments such as fronds or large leaves have large sizes on large hand specimens, indicating also an autochthonous character of the fossils. Samples yielding less than two species (singletons) are far more numerous in the Popa Collection or in other collections surveyed for this study. 


\subsection{Statistic approach}

Altogether, 670 records of 68 taxa distributed in 263 samples were coded as a presence-absence data in a binary 0-1 matrix. They represent a set of a total of 1384 samples gathered in the study area and each of them contains at least two taxa, and each taxon occurred repeatedly at least five times. The joint occurrence of taxa in samples was revealed by a Principal Component Analysis (PCA). PCA is a multivariate method, applied on numerous and variable palynological and palaeontological data (Peyrot et al., 2011). It reduces multi-dimensional hyperspace of species and samples by projection onto three or less principal axes, i.e. the major components of variation (Spicer \& Hill, 1979). The projection of samples was calculated with Principal Coordinate (PCO) analysis on a dissimilarity matrix 1 squared Jaccard binary distances. The goal of PCO is to preserve the distance relationships among objects in a space of reduced dimensionality as well as possible. PCO yielded better polarity for the samples, than PCA, because the arch effect was removed effectively (Alroy, 2015). A logistic regression model, General Linear Model (GLM) that uses the logit link (Agresti, 2007) was applied to relate the binary response of variables (species) to a predictor, i.e. sample loadings along PCO Axes 1 and 2. The binomial distribution of response variables was assumed. A forward (stepwise) selection started from a null model was applied to find best fit model for particular species based on F-test criterion and corresponding I-type error based on 499 runs. The significance level of the tests was established at $\mathrm{p} \leq 0.05$. Calculations were performed with a CANOCO 5 software (ter Braak \& Šmilauer, 2012).

\section{Results}

\subsection{Statistical multivariate analysis}

The first two axes of PCA species ordination explained $18.69 \%$ of the total variance, i.e. $11.15 \%$ and $7.54 \%$, respectively (Fig. $4 a$ ). The first two axes of PCO sample ordination 
explained $12.84 \%$ of the total variance, i.e. $7.34 \%$ and $5.50 \%$, respectively (Fig. $4 b$ ). PCA analysis showed four groups of species (Fig. 4a); one group is represented by one taxon, Nilssonia sp.1. These groups show specific patterns of distribution along the first two PCO axes (Fig. 4b).

Nilssonia undulata (Group 4) occupies the extreme left side of the diagram (Fig. 4c). Group 1 is termed Podozamites group and composed of 3 species. It is best characterized by Podozamites paucinervis (Figs. 4d, 5a) with statistically significant response in GLM analysis $(\mathrm{p} \leq 0.05)$ only along PCO 1 (Table 1). Group 2 is termed Dictyophyllum group, consisting of 7 species. Dictyophyllum nilssonii and Cladophlebis nebbensis can be found in the upper right segment of the diagram, with high positive loadings in PCO 2 (Figs. 4e, 5c, d). Dictyophyllum nervulosum and Neocalamites (Schizoneura) carcinoides are statistically insignificant $(\mathrm{p}>$ 0.05) along PCO 1. Coniopteris murrayana and Matonia braunii are also sub-dominant along PCO 2. Group 3 is termed Ginkgoites group and has high negative loadings in PCO 2. It is characterized by the presence of Cladophlebis denticulata and Zamites schmiedelii (Figs. 4f, 5e, f). Baiera sp. is marginally significant along PCO $2(\mathrm{p}=0.072)$, Ptilophyllum sp. along PCO 1 and Geinitzia sp. has insignificant response along PCO 2 (p $=0.159$ and 0.676, respectively) (Table 1).

Based on the statistical analyses, the ecologically most important taxon (mainly responsible for the total variance) is Nilssonia undulata, shifting to the left side of PCO 1 (Table 1, Fig. 4b-c). Species in Group 1 are placed between Nilssonia undulata (Group 4), and Group 2 and 3, along PCO 1 (Fig. 4b), suggesting the ecological transitory character of Group 1. Groups 2 and 3 form the end-points of PCO 2 (Fig. 4a, e-f), and can be interpreted as having a different ecological profile in relation to Nilssonia undulata and Group 1. Here the most representative species $(0.0001<\mathrm{p}<0.05016)$, placed in the opposite ends of a hypothetical ecological gradient, are distributed along PCO 2, i.e. Schizoneura carcinoides - 
Dictyophyllum nervulosum vs. Ptilophyllum sp. and the marginally significant $(\mathrm{p}=0.0072)$ Baiera sp. (Table 1).

The remote position of Nilssonia undulata may be a sign of its specific character. It could have formed pure stands at the edge of a hypothetical ecological gradient imposed on PCO 1. The ecological counterbalance for Group 1 and Nilssonia undulata formed Groups 2 and 3, otherwise they are well discriminated along PCO 2 (Fig. 4b, e-f).

GLMs visualize trends in response functions of particular groups and show the statistical significance of particular taxa (Fig. 5b-f, Table 1). Nilssonia undulata seems to have a well defined ecological extension. It is separated the most and placed in a remote position along PCO 1 (Figs. 4c, 5b). It had a statistically significant response only along PCO 1 (Table 1), meaning that it could be influenced solely by the ecological gradient imposed on this axis.

Group 1 is plotted in a central position, hence it could be interpreted as having a wider, and unspecific ecological profile. However, it could be linked with an ecological gradient represented by the axis PCO 1 but towards the centre (Figs. 4d, 5a). In Group 2 Neocalamites (Schizoneura) carcinoides and Dictyophyllum nervulosum yielded statistically insignificant ( $\mathrm{p}$ $>0.10$ ) responses along PCO 1 and statistically significant along PCO 2, while Coniopteris murrayana and Matonia braunii gave significant responses only along PCO 1 (Table 1, Fig. 5c, d). In Group 3 Ptilophyllum sp. was statistically (marginally) significant only along PCO 2, and Geinitzia sp. along PCO 1 (Table 1, Fig. 5e-f).

The numerical analysis of palaeobotanical data shows the special ecological position of Nilssonia undulata (Group 4). Ecological profile of Group 1 is less characteristic, and can be associated probably to the same ecological factor as that of Nilssonia undulata, however, in less extreme position. Group 2 and Group 3 occupy the opposite location along PCO 2 representing a given ecological gradient. In Group 2 the species of the most limited ecological 
tolerance, Dictyophyllum nervulosum and Neocalamites (Schizoneura) carcinoides fitted exclusively to the hypothetical ecological gradient imposed on PCO 2. They yielded significant GLM responses $(\mathrm{p} \leq 0.05)$ only along PCO 2. Matonia braunii and Coniopteris murrayana responded significantly $(\mathrm{p}<0.009)$ only along PCO 1 . They may represent an ecological subset of the group. The remaining species of the group: Cladophlebis haiburnensis, C. nebbensis, and Dictyophyllum nilssonii yielded significant responses $(0.00001<\mathrm{p}<0.00057)$ both along PCO 1 and PCO 2. This could be the sign of their wide ecological tolerance. In Group 3 Cladophlebis denticulata, Ginkgoites sp. and Zamites schmiedelii gave significant $(0.0001<\mathrm{p}<0.013)$ responses along both axes, while Geinitiza sp. and Ptilophyllum sp. gave significant responses along PCO 1, and PCO 2 respectively (Table 1).

\subsection{Palaeoecological interpretation}

Ecogroups and their place within ecosystems as well as the mechanisms of their dynamics were discussed in detail by DiMichele \& Gastaldo (2008).

In the present study based on the known environmental requirements of particular taxa (leaf morphology, cuticle structure, analogies with corresponding localities) as well as on sedimentary proxies for Anina (Table 2) PCO axis 1 can be interpreted as disturbance gradient caused by water level fluctuations and axis 2 as temperature gradient which corresponds exactly with the Hettangian/Sinemurian transition. In fact, the assemblages are influenced by several environmental factors but they can be floristically overlapped (DiMichele et al., 2004). According to these gradients Nilssonia undulata (the upper left quarter of the plot, towards lower values of disturbance) can be supposed to prefer relatively undisturbed, not influenced by water stressed conditions corresponding well with the 
requirements of $N$. obtusa and $N$. revoluta from the Mecsek Mts. in Hungary (Barbacka, 2011).

Group 1 can be characterized by affected by none of the factors mentioned a rather wide ecological tolerance affected by none of the factors mentioned above. This group is very characteristic in the shale topping coal seams 1-4 (late Hettangian) in Anina. The composition of the taxa of the group suggests a more advanced succession (mainly trees). Their habitat was less disturbed by floods. Considering palaeoenvironments at Anina, the area of this ecogroup may correspond with levees representing the highest relief in the basin characterized probably by tunnel-forests. One of the group members, Podozamites paucinervis, could also have lived in the swamp or very close to it, however, on a levee.

In Group 2 almost all taxa belong to ferns and some are horsetails (Table 1). Horsetails are represented mostly by Schizoneura, which is the least significant along PCO 1, suggesting its independency from water level fluctuations, however, they prefer somewhat lower temperature. Since the upper right quarter of the plot refers to lower temperature and higher disturbance, this assemblage could be considered as a typical floodplain association. influenced by seasonal changes, thus it may be inferred as a colonizer vegetation. A scattered occurrence in the central and left part of the diagram could have reflected its ability to inhabit the sites in a type of habitat of Podozamites paucinervis (Table 2).

Group 3 is a developed succession with gingkoaleans and bennettitaleans and a small number of ferns. It is opportunistic to all other groups along the gradient of temperature and placed in the lower part of the plot reflecting higher temperature and higher disturbance. Plants of this group are secondary coal generators and their fossils are constantly found in the topping shale of coal seams 6,7 and 8 (Sinemurian in age) although they are not hydrophilous ones. This group may be associated with the swampy areas in its last, closing moments, when 
they were being filled with sediments, occupying the new habitat. It is a ubiquitous, ternary association in Anina (Popa, 2014).

The investigated plants could dwell in the following circumstances: a) in the water (in lakes, in mires) along the shores, not in the middle of these water bodies where only planktonic algae occurred, such as Botryococcus; b) on the shores of stagnant water bodies, on dry land; c) in dry habitats characterized by seasonal floods washing periodically the whole area. Geomorphologically considering the facies model relevant for Anina Basin a) represents active channels, oxbow lakes of the meander belts and stagnant lakes of the floodplain, b) represents levees and crevasse splays and c) represents the floodplain basins.

\section{Discussion}

Plant ecogroups and their connection with different gradients of environmental changes were studied using various statistical methods. DiMichelle et al. (2007) used Nonmetric multidimensional scaling (NMDS) to find similarities and differences among predetermined groups of species in Pennsylvanian forests. The main grouping factor was facies (landward and seaward communities). Detrended correspondence analysis (DCA) based ecogroup models related to the Jurassic of Mecsek Mts. (Hungary) were established by Barbacka (2011) for delta environments. The main factors influencing the composition of the obtained five ecogroups were disturbance and moisture. The same statistical method (DCA) was applied to estimate long-term climatic change at the $\operatorname{Tr} / \mathrm{J}$ boundary (McElwain et al., 2007). The Jurassic Yorkshire Hasty Bank locality was sampled layer by layer and the quadrate data was analyzed using PCA and Correspondence analysis (CA) (Spicer \& Hill, 1979). Group differentiation was based on lithological data.

Ecological plant grouping was the subject of several other studies, as well. Wing et al. (2012) used DCA, CCA and NMDS for determining plant assemblages and their 
environmental preferences in Late Cretaceous wetlands. The major influencing factors in his study were nutrient, stress and disturbance. Based on the sedimentary conditions and taxa cooccurrences, wetter and drier conditions as well as substrate based succession stages were distinguished in floodplain, wetland and partly marine sedimentary environments (Spicer et al., 2002).

Usually, when ecological background factors can be interpreted water and disturbance are decisive which is not surprising in wetland communities. Generally, wetland communities are overrepresented because of taphonomic reasons (DiMichelle \& Gastaldo, 2008). In this study the temperature gradient was already known from different proxies (see chapter 2, Geological and palaeobotanical background) and multivariate analyses indicated that this factor really had high impact on ecogroup differentiation.

Ecogroups show no stable characters, they change in space and time and their composition can also change according to competition between taxa (Di Michele \& Gastaldo, 2008). Using statistical analyses we obtain a hypothetic model reflecting rather potential composition of assemblages and their relation to local circumstances and not to strictly determined units.

A statistical approach does not change general plant grouping on the basis of field observations and known environmental requirements of certain taxa. However, this method can provide new insights. Field experience enables broader interpretation of tendencies in plant-environment relationships and makes possible preliminary assemblage reconstruction. However, the multivariate approach can deal with high number of data or hardly detected, but important information and refine the results, providing at the same time objective and independent support.

There are some improvements regarding preliminary established ecogroups from Anina. The temperature based ecogroups of Hettangian and Sinemurian are distinguished 
clearly. Hettangian taxa (over axis 1 on Fig. 5) appear to represent a wider spectrum of adaptation forming three ecogroups based on the tolerance for water table fluctuations, while Sinemurian taxa form one group hardly influenced by disturbance. Nilssonia undulata, which was interpreted as a dry land dweller, in areas of floodplains or levees, and associated with ferns, based on the present study forms a separate group with stronger defined requirements

402 than assumed before. The ferns from the same ecogroup appeared to have opposite trends being much more tolerant for disturbance. Although Cladophlebis denticulata and Dictyophyllum nilssonii belong to similar habitats they show different temperature preferences. Although Neocalamites (Schizoneura) carcinoides, was placed in the same ecogroup as ferns, appears in extreme positions (a plant growing always in water).

This study helped also the classification of some taxa into defined ecogroups which have not been classified yet. Thus their environmental preferences were identified as well. The use of GLM illustrated well and supported the environmental trends of individual taxa making them robust and reliable.

The disadvantage of the applied method is that it could not deal with singletons (specimens with only one taxon), therefore some taxa could not be analyzed (e.g. some of the analyzed ones co-occurred with others only during Hettangian (Dictyophyllum nilssonii and Neocalamites (Schizoneura) carcinoides) or Sinemurian (Cladophlebis denticulata)). Although such hand specimens with singletons were collected, often from underground galleries and extraction chambers in which roof shale, coal beds or palaeosols were sampled in difficult field conditions, they were not included in this statistical approach. In underground conditions, in galleries the outcrop surfaces are only a few square metres and the surface of the collected samples is generally rather small therefore singletons occur more often in such samples. Although they were recorded from underground sites with their entire taxonomical 

422 plots.

423

424

425

426

427

428

429

\section{3}

associations (Popa, 1992, 2000a, 2009) their transitional character was not indicated in the

\section{Conclusions}

The numerical analysis of palaeobotanical data presented here gives deeper insight into the ecological context of the described ancient taxa. The joint distribution of species along the orthogonal axes of PCA analysis enables the estimation of their putative ecological profiles. The joint occurrence of a group of species in a group of samples (displayed along PCO axes) indicates their similar environmental requirements. The mathematical orthogonality (non-correlation) of the axes ensures no redundancy (independence) of the inferred ecological gradients. Independent data, like morphological similarities, seen mostly in the structure of macro- and micro-morphology (cuticle), can confirm the results of the community level ecological approach.

\section{Acknowledgements}

This study was supported by the Hungarian National Science Foundation (grant OTKA 100658), as well as by the W. Szafer Institute of Botany, Polish Academy of Sciences through its statutory funds. We wish to thank the staff of the Geological Museum (Geological Institute of Romania) in Bucharest for permitting access to the fossil plant collections. This study was also supported by the Romanian National University Research Council (NURC-CNCSIS) grant no. 436/2007 for one of the authors (MEP). The work was also supported by the MFGI 11.1 National project. 


\section{References}

Alroy, J., 2015. A simple way to improve multivariate analyses of paleoecological data sets. Paleobiology 41, 377-386.

Abbink, O., 1998. Palynological investigations in the Jurassic of the North Sea region. LPP Contributions Series 8. LPP Foundation, Utrecht.

Abbink, O., Targarona J., Brinkhuis H., Visscher H., 2001. Late Jurassic to earliest Cretaceous palaeoclimatic evolution of the southern North Sea. Global and Planetary Change 30, 231-256.

Abbink, O., van Konijenburg-van Cittert, J.H.A., Visscher, H., 2004. A sporomorph ecogroup model of the Northwest European Jurassic Lower Cretaceous: concepts and framework. Geologie en Mijnbouw 83, 17-38.

Antonescu, E., 1973. Quelques donnees sur la palynologie du Lias sous facies de Gresten de Roumanie, 3rd International Palynological Conference. Moscow, 13-17.

Agresti, A., 2007. An Introduction to Categorical Data Analysis. John Wiley \& Sons Inc., Hoboken, New Jersey.

Andrae, C., 1855. Beitrage zur kenntniss der fossilen Flora Siebenburgens und des Banates. Abhandlungen der kaiserlich-koniglich geologischen Reichsanstalt III, 1-48.

Barbacka, M., 2011. Biodiversity and the reconstruction of Early Jurassic flora from the Mecsek Mountains (Southern Hungary). Acta Palaeobotanica 51 (2), 127-179.

Barbacka, M., Popa, M., Mitka, J., Bodor, E., Pacyna, G., 2015: Relationships between ecosystems and plant assemblages as responses to environmental conditions in the Lower Jurassic of Hungary and Romania. Acta Palaeobotanica, 55 (1), 3-17.

Bercovici, A., Diez, J.B., Broutin, J., Bourquin, S., Linol, B.,Villanueva-Amadoz, E.U., López-Gómez, J., Durand, M., 2009. A palaeoenvironmental analysis of Permian 
sediments in Minorca (Balearic Islands, Spain) with new palynological and megafloral data. Rev. Palaeobot. Palynol., 158, 14-28.

Bonis, N.R., van Konijnenburg-van Cittert, J.H.A., Kürschner, W.M., 2010. Changing $\mathrm{CO}_{2}$ conditions during the end-Triassic inferred from stomatal frequency analysis on Lepidopteris ottonis (Goeppert) Schimper and Ginkgoites taeniatus (Braun) Harris. Palaeogeogr. Palaeoclimat. Palaeoecol., 295, 146-161.

Botfalvai, G., Haas, J., Bodor, E.R., Mindszenty, A., Ösi, A., 2016. Facies architecture and palaeoenvironmental implications of the Upper Cretaceous (Santonian) Csehbánya Formation at the Iharkút vertebrate locality (Bakony Mts., Northwestern Hungary). Palaeogeography Palaeoclimatology Palaeoecology, 441, 659-678.

Bucur, I.I., 1991. Proposition pour une nomenclature formelle des depots paleozoiques et mesozoiques de la zone de Reşiţa-Moldova Nouă (Carpathes Meridionales, Roumanie). Studia Universitatis Babeş-Bolyai, Geologie XXXVI, 3-14.

Bucur, I.I., 1997. Formaţiunile mesozoice din zona Reşiţa-Moldova Nouă. Cluj-Napoca: Presa Universitară Clujeană.DiMichele, W.A., Beal, S.B., 1990. Flora, fauna, paleoecology of the Brazil Formation of Indiana. Rocks Miner., 65, 244-250.

DiMichele, W.A., Beall, B.S., 1990. Flora, fauna and paleoecology of the Brazil Formation of Indiana. Rocks \& Minerals, 65, 244-250.

DiMichele, W.A., Gastaldo, R.A., 2008. Plant paleoecology in deep time. Ann. Missouri Bot. Gard., 95, 144-198.

DiMichele, W.A., Phillips, T.L., 1994. Paleobotanical and paleoecological constraints on models of peat formation in the Late Carboniferous of Euramerica Palaeogeogr. Palaeoclimat. Palaeoecol., 106, 39-90. 
DiMichele, W.A., Behrensmeyer, A. K., Olszewski, T. D., Labandeira, C. C., Pandolfi, J. M., Wing S. L., Bobe, R., 2004. Long-term stasis in ecological assemblages: Evidence from the fossil record. Ann. Rev. Ecol. Evol. Syst., 35, 285-322.

DiMichele, W.A., Falcon-Lang, H.J,. Nelson, W.J., Elrick, S.D., Ames, P.R., 2007. Ecological gradients within a Pennsylvanian mire forest. Geology 35, 415-418.

DiMichele, W.A., Kerp, H., Tabor, N.J., Looy, C.V., 2008. The so-called "PaleophyticMesophytic" transition in equatorial Pangea - Multiple biomes and vegetational tracking of climate change through geological time. Palaeogeogr. Palaeoclimat. Palaeoecol. 268, 152-163.

Ettingshausen, C., 1852. Uber die fossilen Pflanzen von Steierdorf in Banat. Jahrbuch der Kaiserlich-Koniglichen Geologische Reichsanstalt.

Falcon-Lang, H.J., Nelson, W.J., Elrick, S., Looy, C.V., Ames, P.R., DiMichele, W.A., 2009. Incised channel fills containing conifers indicate that seasonally dry vegetation dominated Pennsylvanian tropical lowlands. Geology 37(10), 923-926.

Foetterle, F., 1850. Verzeichniss der an die K.K. geologische Reichsanstalt gelangten Eisendungen von Mineralien, Petrefacten Gebirgsarten u.s.w. Jahrbuch der KaiserlichKoniglichen Geologische Reichsanstalt 1, 350-358.

Francis, J.E., Ashworth, A., Cantrill, D.J., Crame, J.A., Howe, J., Stephens, R., Tosolini, A.M., Thorn, V., 2008. 100 Million Years of Antarctic Climate Evolution: Evidence from Fossil Plants: 19-28. In: Cooper A.K., Barrett P.J., Stagg H., Storey B., Stump E., Wise W., and the 10th ISAES editorial team (eds), Antarctica: A Keystone in a Changing World. Proceedings of the 10th International Symposium on Antarctic Earth Sciences. Washington, DC: The National Academies Press.

Gastaldo, R.A., Stevanovic-Walls, I., Ware, W.N., Greb, S.F., 2004. Community heterogeneity of Early Pennsylvanian peat mires. Geology 32, 693-696. 
Givulescu, R., 1998. Flora fosilă a Jurasicului inferior de la Anina, 1 ed. Bucureşti: Editura Academiei Române.

Gordenko, N.V., 2008. Middle Jurassic Flora of the Peski Locality (Moscow Region). Systematics, Paleoecology, and Phytogeography. Paleont. Jour., 42 (12): 1285-1382.

Hámor-Vidó, M., 2004. Coal facies studies in Hungary: a historical review. International Journal of Coal Geology 58, 91- 97.

Harris, T.M., 1937. The fossil flora of Scoresby Sound East Greenland. Part 5: Stratigraphic relations of the plant bed. Medd. Grønland, 112(2): 1-114.

Harris, T.M., 1961. The Yorkhire Jurassic Flora. I: Thallophyta - Pteridophyta. Trustees of the British Museum, London.

Harris, T.M., 1964. The Yorkshire Jurassic Flora. II: Caytoniales, Cycadales \& Pteridosperms. Trustees of the British Museum (Natural History), London.

Harris, T.M., 1969. The Yorkshire Jurassic Flora. III. Bennettitales. Trustees of the British Museum (Natural History), London.

Harris, T.M., Millington, W., 1974. The Yorkshire Jurassic flora IV. Ginkgoales. Trustees of the British Museum (Natural History), London.

Hesselbo, S.P., Morgans-Bell, H.S., McElwain, J.J., Rees, P.McA., Robinson, S.A., Ross, C.E., 2003. Carbon-cycle perturbation in the Middle Jurassic and accompanying changes in the terrestrial paleoenvironment. The Journal of Geology 111, 259-27.

Kędzior, A., Popa, M.E., 2013. Sedimentology of the Early Jurassic terrestrial Steierdorf Formation in Anina, Colonia Cehă Quarry, South Carpathians, Romania. Acta Geologica Polonica 63, 175-199.

van Konijnenburg-van Cittert, J.H.A., van der Burgh, J., 1996. Review of the Kimmeridgian flora of Sutherland, Scotland, with reference to the ecology and in situ pollen and spores. Proceedings of the Geologists' Association 107, 97-105. 
van Konijnenburg-van Cittert, J.H.A., 2002. Ecology of some Late Triassic to Early Cretaceous ferns in Eurasia. Rev. Palaeobot. Palynol., 119, 113-124.

Kustatscher, E., van Konijnenburg-van Cittert, J.H.A., Roghi, G., 2010. Macrofloras and palynomorphs as possible proxies for palaeoclimatic and palaecological studies: A case study from the Pelsonian (Middle Triassic) of Kuhwiesenkopf/Monte Pra della Vacca (Olang Dolomites, N-Italy). Palaeogeography Palaeoclimatology Palaeoecology 290, $71-80$.

Libertin, M., Dašková, J., Opluštil, S., Bek, J., Edress, N., 2009. A Palaeoecological model for a vegetated early Westphalian intramontane valley (Intra- Sudetic basin, Czech Republic). Rev. Palaeobot. Palynol., 155, 175-203.

McElwain, J.C., Popa, M.E., Hesselbo, S.P., Haworth, M., Surlyk, F., 2007. Macroecological responses of terrestrial vegetation to climatic and atmospheric change across the Triassic/Jurassic boundary in East Greenland. Paleobiology 33, 547-573.

Pálfy, J., Kocsis, Á.T., 2014. Volcanism of the Central Atlantic magmatic province as the trigger of environmental and biotic changes around the Triassic-Jurassic boundary. The Geological Society of America, Special Paper 505, 245-261.

Peyrot, D., Barosso-Barcenilla, F., Barrón, E., Comas-Rengifo, M.J. 2011. Palaeoenvironmental analysis of Cenomanian-Turonian dinocyst assemblages from the Castilian Platform (Northern-Central Spain). Creataceous Research 32, 504-526.

Phillips, T.L., Peppers, R.A., 1984. Changing patterns of Pennsylvanian coal-swamp vegetation and implications of climatic control on coal occurrence. Int. J. Coal Geol. 3, $205-255$.

Pieńkowski, G., Popa, M.E., Kędzior A., 2009. Early Jurassic sauropod footprints of the Southern Carpathians, Romania: palaeobiological and palaeogeographical significance. Geological Quarterly 53, 461-470. 
Popa, M.E., 1992. The Early Liassic of Anina: New Paleobotanical Aspects. Documenta Naturae 1-3, 1-9.

Popa, M.E., 1997a. Liassic ferns from the Steierdorf Formation, Anina, Romania, 4th European Palaeobotanical and Palynological Conference. Heerlen: Mededelingen Nederlands Instituut voor Toegepaste Geowetenschappen TNO, 139-148.

Popa, M.E., 1997b. Corystospermal pteridosperms in the Liassic continental deposits of Romania. Acta Palaeontologica Romaniae, 1, 81-87.

Popa, M.E., 1998. The Liassic continental flora of Romania: Systematics, Stratigraphy and Paleoecology. Acta Botanica Horti Bucurestensis 1, 177-184.

Popa, M.E., 2000a. Early Jurassic Land Flora of the Getic Nappe. PhD thesis, Faculty of Geology and Geophysics, Bucharest

Popa, M.E., 2000b. Aspects of Romanian Early Jurassic palaeobotany and palynology. Part III. Phytostratigraphy of the Getic Nappe. Acta Palaeontologica Romaniae 2, 377-386.

Popa, M.E., 2005. Aspects of Romanian Early Jurassic Palaeobotany and Palynology. Part VI. Anina, an exceptional locality. Acta Palaeontologica Romaniae 5, 375-378.

Popa, M.E., 2009. Late Palaeozoic and Early Mesozoic Continental Formations of the Reşiţa Basin. Editura Universităţii din Bucureşti, Bucharest

Popa, M.E., 2011. Field and laboratory techniques in plant compressions: an integrated approach. Acta Palaeontologica Romaniae 7, 279-283.

Popa, M.E., 2014. Early Jurassic bennettitalean reproductive structures of Romania. Palaeobiodiversity and Palaeoenvironments 94, 327-362.

Popa, M.E., Kędzior, A., 2008. High resolution paleobotany and sedimentology of the Steierdorf Formation, Reşiţa Basin, in: Bucur, I.I., Filipescu, S. (Eds.), Annual scientific session "Ion Popescu Voiteşti". Cluj-Napoca: Cluj University Press, 57-59. 
Popa, M.E., van Konijnenburg-van Cittert, J.H.A., 1999. Aspects of Romanian Early Jurassic palaeobotany and palynology. Part I. In situ spores from the Getic Nappe, Banat, Romania. 5th EPPC, W. Szafer Institute of Botany, Krakow, 181-195.

Popa, M.E., van Konijnenburg-van Cittert, J.H.A., 2006. Aspects of Romanian Early - Middle Jurassic palaeobotany and palynology. Part VII. Successions and floras. Progress in Natural Sciences 16, 203-212.

Popa, M.E., Meller, B., 2009. Review of Jurassic plants from the Anina (Steierdorf) coal mining area, South Carpathians, int he collections of the Geological Survey of Austria. Jahrbuch der Geologischen Bundesanstalt, 149(4), 487-498.

Schweitzer, H.J., Van Konijnenburg-van Cittert, J.H.A., Van der Burgh, J., 1997. The RhaetoJurassic flora of Iran and Afganistan. 10. Bryophyta, Lycophyta, Sphenophyta. Pterophyta - Eusporangiatae and Protoleptosporangiatae. Palaeontographica B 243 (46), 103-192.

Semaka, A., 1962. Asupra Rheticului de la Bigăr. Dări de Seamă ale Şedinţelor Comitetului Geologic, XLV: 173-176.

Sheldon, N.D., Tabor, N.J., 2009. Quantitative paleoenvironmental and paleoclimatic reconstruction using paleosols. Earth Sci. Rev., 95(1-2): 1-52.

Spicer, R., Hill, C.R., 1979. Principal components and correspondence analyses of quantitative data a Jurassic plant bed. Review of Palaeobotany and Palynology 28, 273299.

Spicer, R.A., Parrish J.T., 1990. Late Cretaceous-early Tertiary palaeoclimates of northern high latitudes: a quantitative view. Journal of the Geological Society, London, 147, 329341. 
Spicer, R.A., Parrish, J.T., Grant, P.R., 1992. Evolution of vegetation and coal-forming environments in the Late Cretaceous of North Slope of Alaska, GSA Special Paper, 267, 177-192.

Spicer, R.A., Ahlberg, A., Herman, A.B., Kelley, S.P., Raikevich, M.I., Rees, P.M., 2002. Palaeoenvironment and ecology of the Middle Cretaceous Grebenka Flora of northeastern Asia. Palaeogeogr. Palaeoclimatol. Palaeoecol. 184, 65-105.

ter Braak, C.J.F., Šmilauer, P., 2012. Canoco Reference Manual and User's Guide. Software for Ordination (version 5.0), Microcomputer Power, Ithaca, USA

Thorn, V., 2001. Vegetation communities of a high palaeolatitude Middle Jurassic forest in New Zealand. Palaeogeography Palaeoclimatology Palaeoecology 168, 273-289.

Wang, Y., 2002. Fern ecological implications from the Lower Jurassic in Western Hubei, China. Rev. Palaeobot. Palynol., 119: 125-141.

Wing, S. L., DiMichele W.A., 1995. Conflict between local and global changes in plant diversity through geological time. Palaios 10, 551-564.

Wing, S.L., Strömberg, C.A.E., Hickey, L.J., Tiver, F., Willis, B., Burnham, R.J., Behrensmeyer A.K. 2012. Floral and environmental gradients on a Late Cretaceous landscape. Ecological Monographs, 82(1), 23-47.

Zhou Z.Y., 2009. Review: An overview of fossil Ginkgoales. Palaeoworld 18, 1-22.

\section{Figure captions}

Fig. 1. Location of Anina (Steierdorf) fossile Lagerstatte locality, Caraş-Severin County, central area of the Reşiţa Basin, Getic Nappe, South Carpathians, Romania.

Fig. 2. Synthetic stratigraphic log of the Hettangian - Sinemurian Steierdorf Formation, with its eight coal seams and main fossiliferous plant levels. 
Fig. 3. Examples of fossil plant species of the Steierdorf Formation in Anina. a. Zamites schmiedelii (Sternberg in Presl) Andrae 1855 (Bennettitales, Williamsoniaceae), Sinemurian, leaf fragments IB29/Fn, I. Z. Barbu Collection; b. Cladophlebis denticulata (Brongniart) Fontaine 1889 (Filicales, Incertae sedis), leaf fragment P41/C2/S6/14E/F1, Hettangian, Ponor Quarry; c. Dictyophyllum nilssonii (Brongniart) Goeppert 1846 (Filicales, Dipteridaceae), leaf fragment P109/C1/1/F1, indicated in the figure with (1), Cladophlebis nebbensis (Brongniart) Nathorst 1876 (Filicales, Incertae sedis), leaf fragments P109/C1/1/Fn, indicated in the figure with (2), and Cladophlebis sp., indicated in the figure with (3), roof shale of the Coal seam no. 2, Zona Nouă Coalfield, 8th Underground Horizon, Gallery 442 South, Hettangian, M. E. Popa Collection. Supplementary hand drawings of leaf fragments occurring on sample P109/C1/1 were given by Popa (1997a); d. Podozamites paucinervis (Coniferales, Incertae sedis), Hettangian, Ponor Quarry, leaf fragment P40/C2/22/Fn, M. E. Popa Collection; e. Nilssonia undulata (Cycadales, Nilssoniaceae), Hettangian, Ponor Quarry, leaf fragment P40/C2/22/Fn, M. E. Popa Collection. Hand specimens curated at the University of Bucharest, Laboratory of Palaeontology and Museum of Geology (Geological Institute of Romania). Collecting, labeling, recording and photographing methods detalied in Popa (2011). All scale bars: $10 \mathrm{~mm}$.

Fig. 4 a - Principal Component Analysis of species data (arrows), only species with statistically significant responses $₫(p .072)$ are marked; b - Biplot of Principal Coordinate projection of the samples (circles) based on 1 - squared Jaccard binary distances (dissimilarity) and four groups of species (marked with colours) distinguished; c - Nilssonia sp1; d - Group 1 (Pinites sp., Podozamites paucinervis, Sphenobaiera sp.); e - Group 2 (Cladophlebis haiburnensis, Cladophlebis nebbensis, Coniopteris murrayana, Dictyophyllum nervulosum, Dictyophyllum nilssonii, Matonia braunii, 


\section{Table caption}

674 type error. Anina.

Neocalamites (Schizoneura) carcinoides); f - Group 3 (Baiera sp., Cladophlebis denticulata, Geinitzia sp., Ginkgoites sp., Ptilophyllum sp., Zamites schmiedelii). The same pattern of response (decreasing or increasing) in a group of species means their similar ecological profile. Differences in shapes of response curves depend on the distribution and abundance of species along a putative environmental gradient.

Fig. 5 Logistic regressions of GLM for response variables (species) in four palaeoecological species groups along PCO 1 and PCO 2. a - Group 1, PCO 1; b - Nilssonia sp.1; c Group 2, PCO 1; d - Group 2, PCO 2; e - Group 3, PCO 1; f - Group 3, PCO 2

Table 1 Stepwise selection of response variables in three groups of species discriminated in PCA analysis, according to logistic regression model with logit link function and binomial response assumed. $\mathrm{R}^{2}$ - coefficient of determination, $\mathrm{F}-\mathrm{a}$ partial $\mathrm{F}$ test, $\mathrm{p}-\mathrm{I}$ -

Table 2 Environmental requirements of the most important species forming ecogroups in 


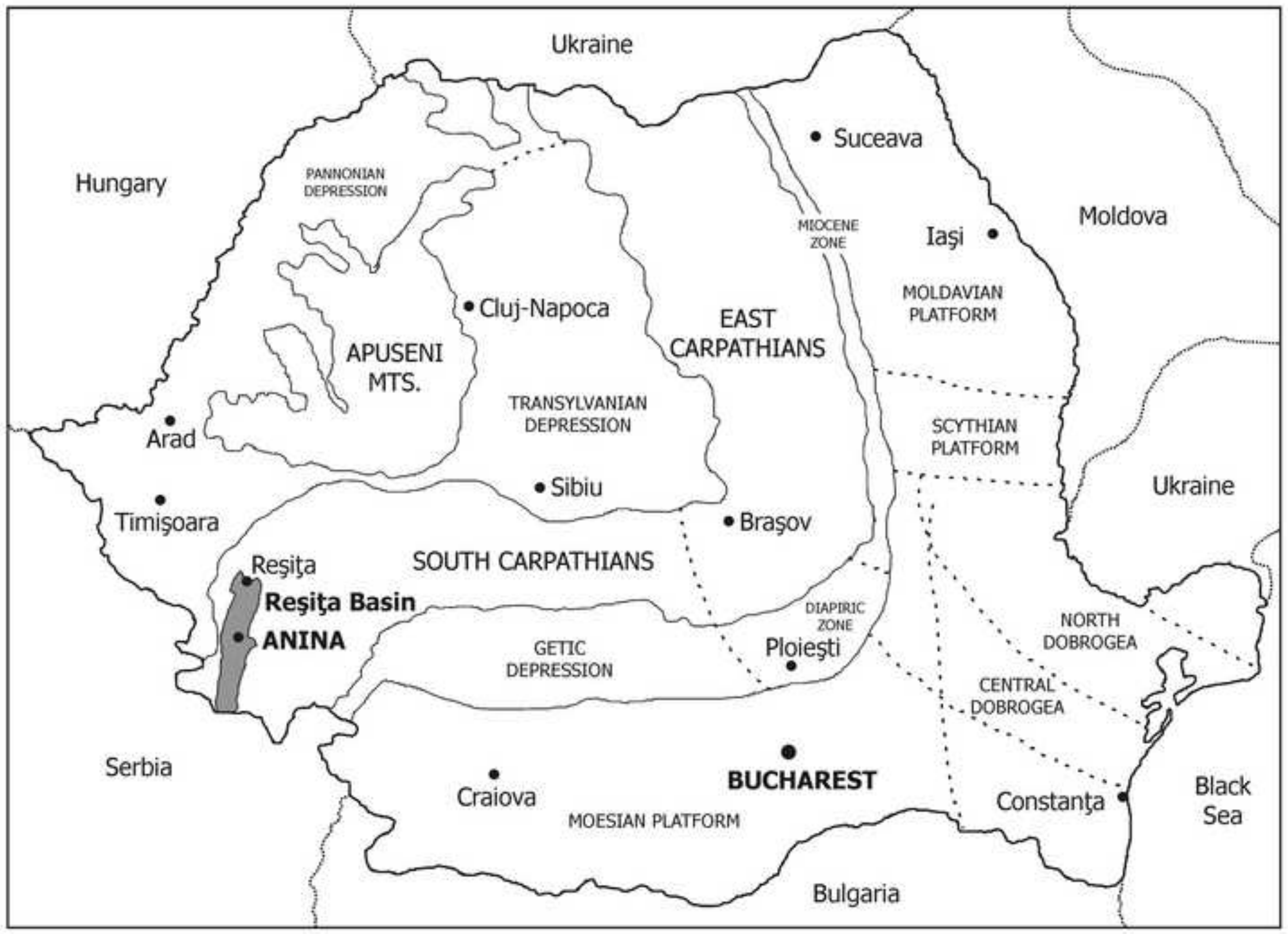




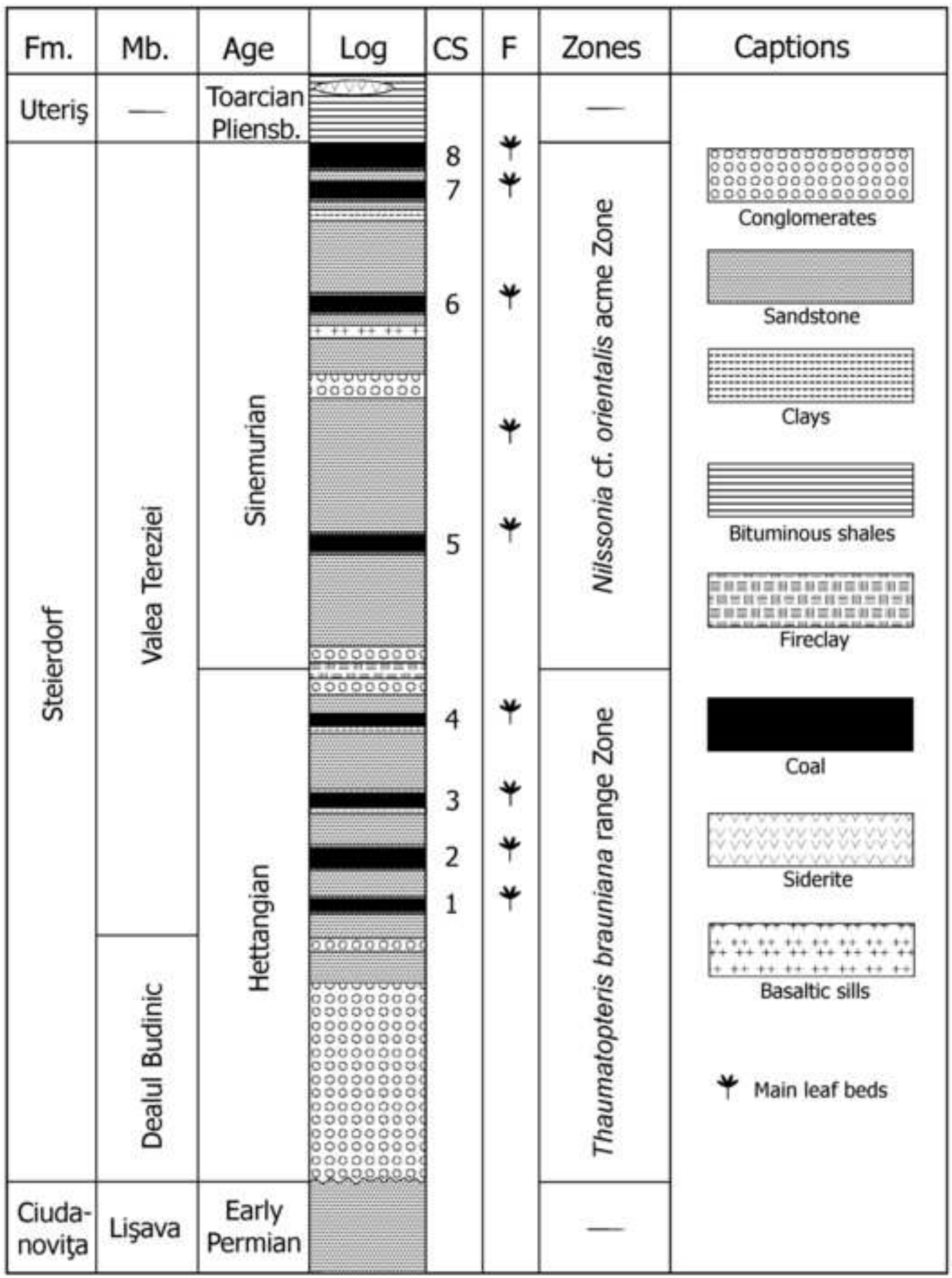



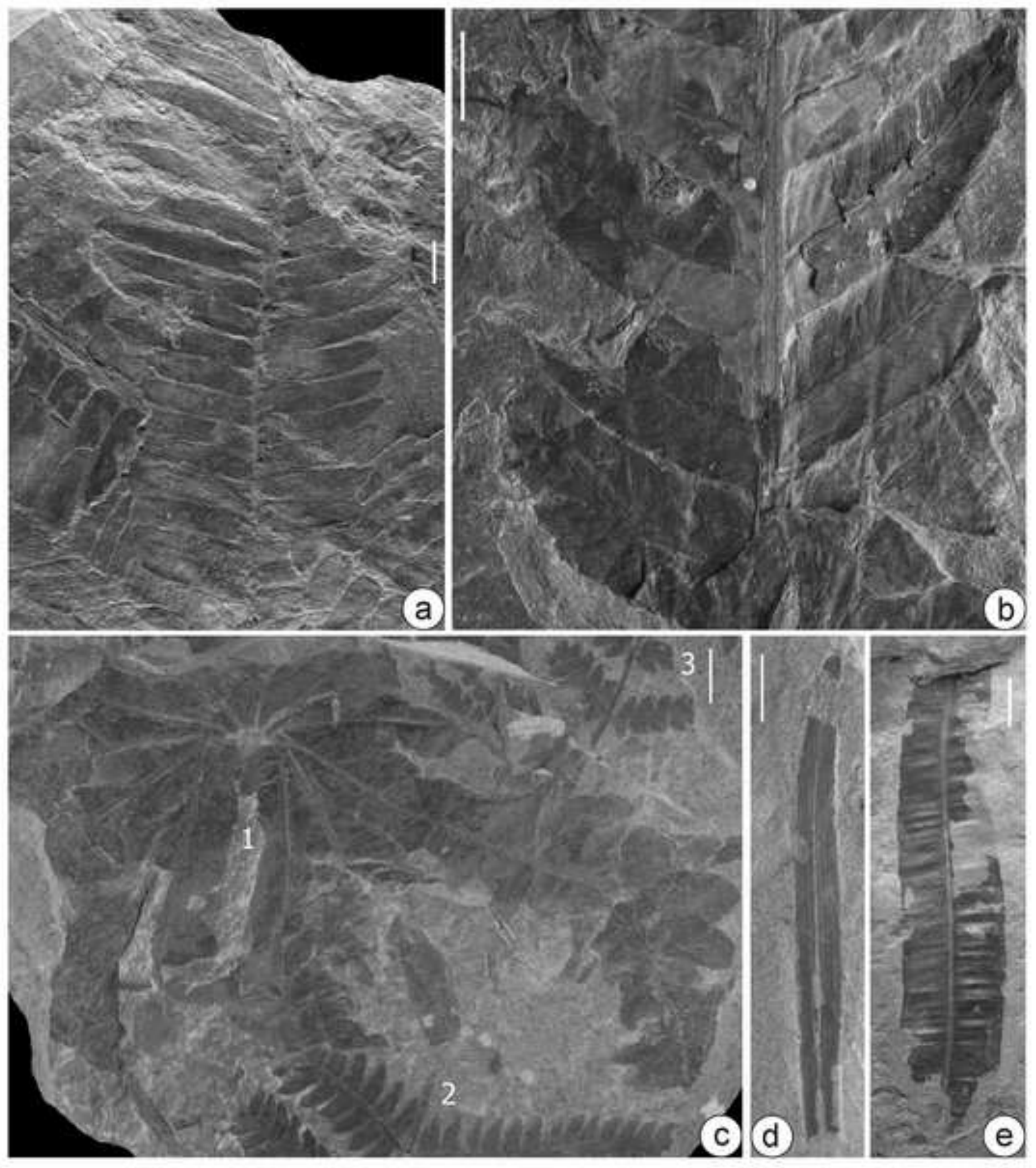

Figure 3

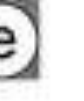

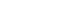

3

.
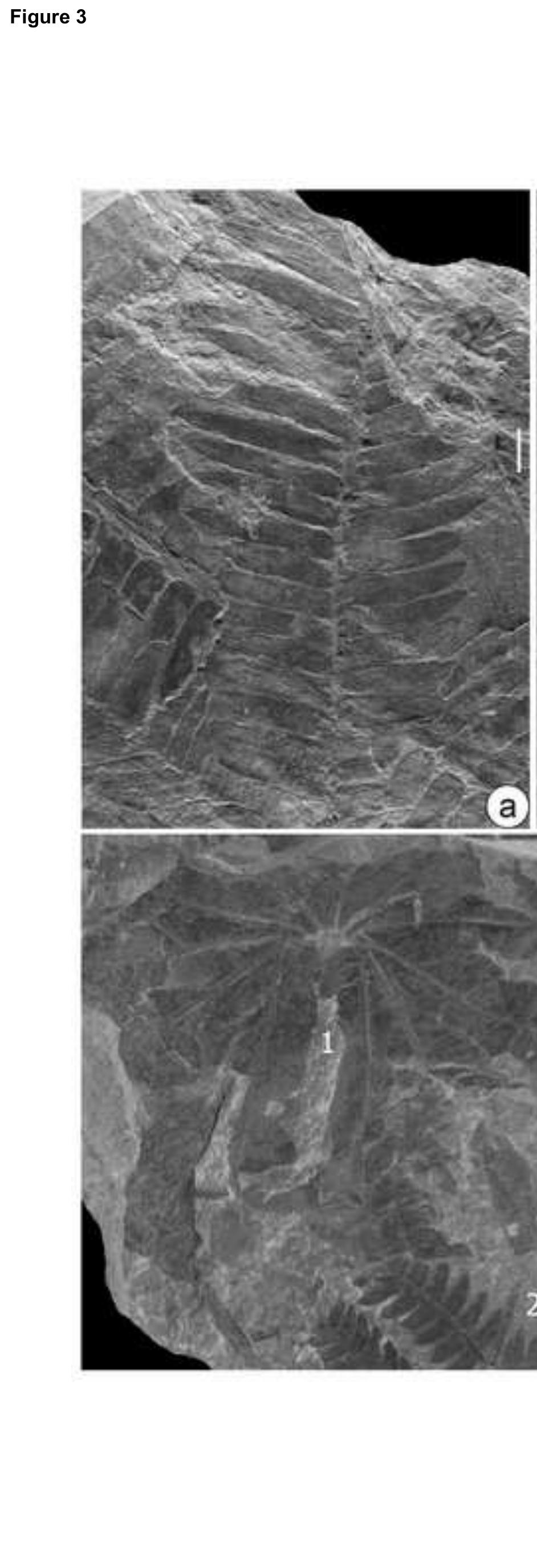


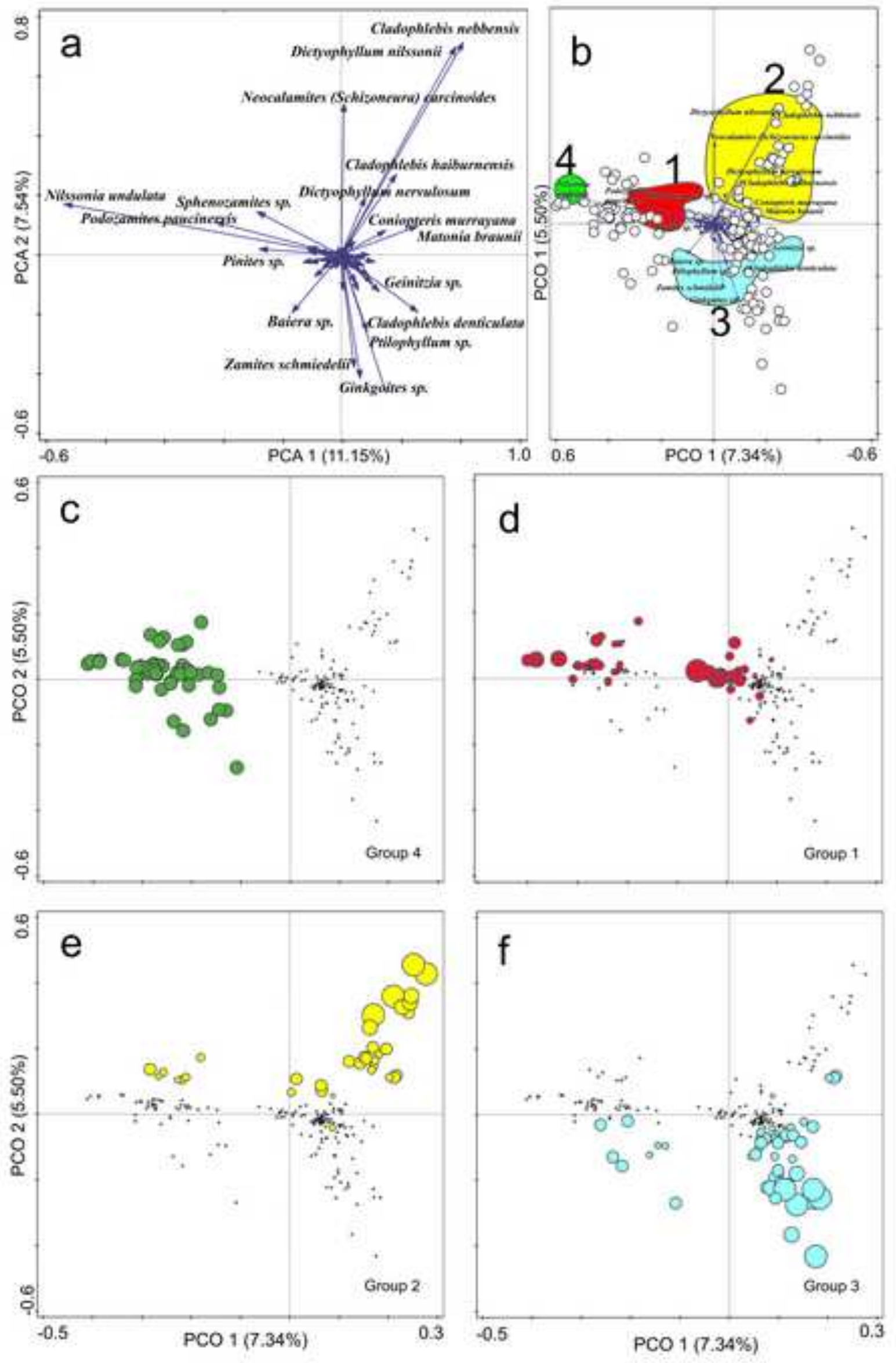


Figure 5
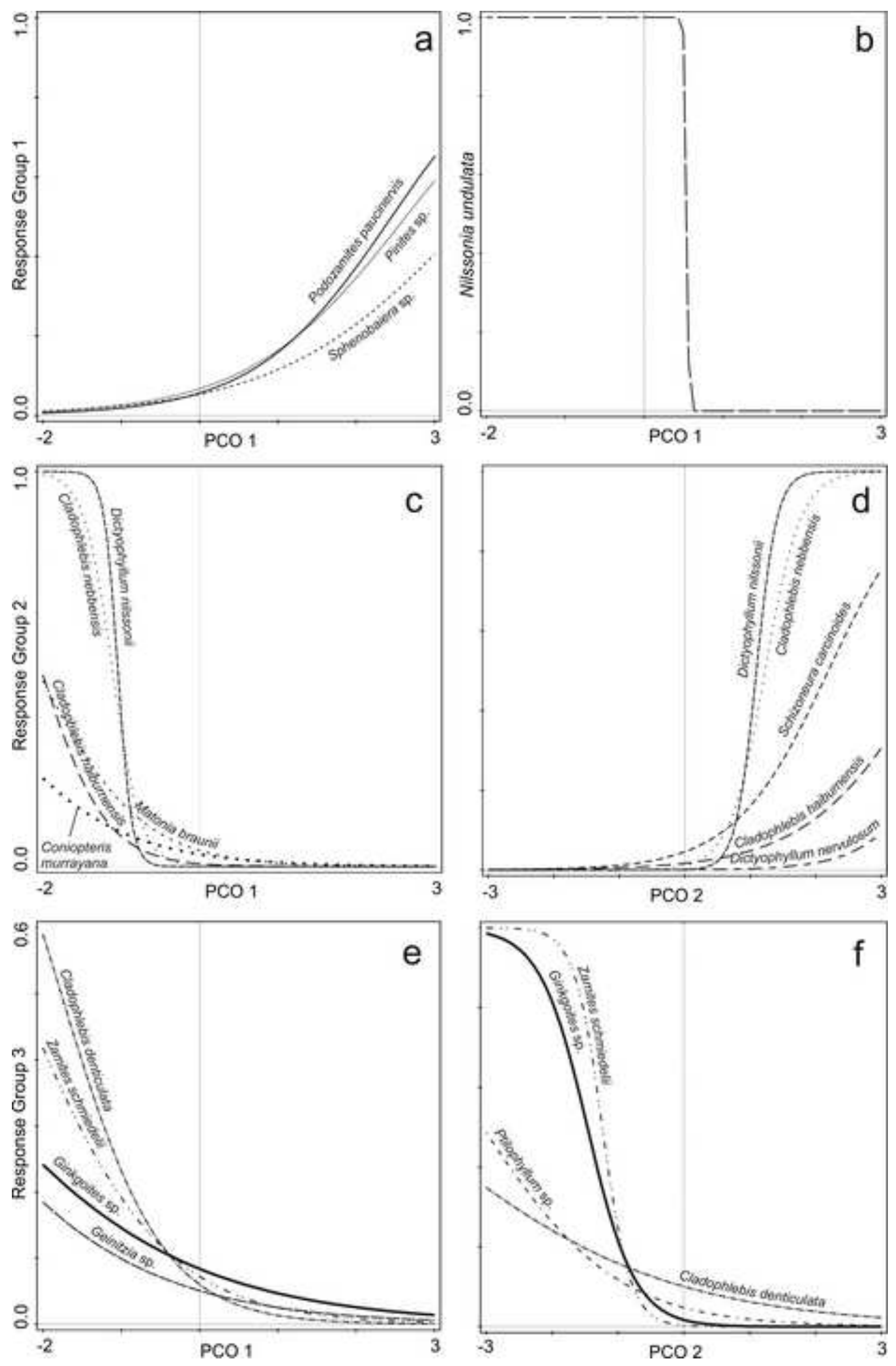


\begin{tabular}{|c|c|c|c|c|c|c|}
\hline Response & $\mathrm{R} 2[\%]$ & $\mathrm{F}$ & $\mathrm{p}$ & $\mathrm{R} 2[\%]$ & $\mathrm{F}$ & $\mathrm{p}$ \\
\hline Axis & PCO1 & \multicolumn{5}{|c|}{ PCO2 } \\
\hline & \multicolumn{6}{|c|}{ Nilssonia } \\
\hline \multirow[t]{2}{*}{ Nilssonia sp. 1} & 100 & 312.6 & $<0.00001$ & 0.8 & 2.50 & 0.11453 \\
\hline & \multicolumn{6}{|c|}{ Group 1} \\
\hline Pinites sp. & 14.9 & 25.2 & $<0.00001$ & 0.5 & 0.82 & 0.63366 \\
\hline Podozamites paucinervis & 18.7 & 30.8 & $<0.00001$ & 0.6 & 0.97 & 0.67445 \\
\hline \multirow[t]{2}{*}{ Sphenobaiera sp. } & 10.1 & 13.7 & 0.00026 & 1.5 & 2.10 & 0.14949 \\
\hline & \multicolumn{6}{|c|}{ Group 2} \\
\hline $\begin{array}{l}\text { Cladophlebis } \\
\text { haiburnensis }\end{array}$ & 17.1 & 12.2 & 0.00056 & 17 & 12.20 & 0.00057 \\
\hline Cladophlebis nebbensis & 48.9 & 85.1 & $<0.00001$ & 69.1 & 120.20 & $<0.00001$ \\
\hline Coniopteris murrayana & 7.2 & 7 & 0.00861 & 2.9 & 2.80 & 0.09389 \\
\hline $\begin{array}{l}\text { Dictyophyllum } \\
\text { nervulosum }\end{array}$ & 20 & 2.6 & 0.10604 & 29.5 & 3.90 & 0.05016 \\
\hline Dictyophyllum nilssonii & 73.9 & 125.5 & $<0.00001$ & 83.7 & 142.10 & $<0.00001$ \\
\hline Matonia braunii & 12 & 17 & 0.00005 & 2.2 & 3.10 & 0.08072 \\
\hline \multirow[t]{2}{*}{ Schizoneura carcinoides } & 0.1 & 0.2077 & 0.64899 & 27 & 42.10 & $<0.00001$ \\
\hline & \multicolumn{6}{|c|}{ Group 3} \\
\hline Baiera sp. & 4.6 & 1.1 & 0.29921 & 13.9 & 3.30 & 0.07212 \\
\hline Cladophlebis denticulata & 13.5 & 24.7 & $<0.00001$ & 3.6 & 6.60 & 0.01054 \\
\hline Geinitzia sp. & 4.2 & 5.1 & 0.02486 & 0.8 & 0.98 & 0.67644 \\
\hline Ginkgoites sp. & 3.8 & 6.2 & 0.01323 & 52.9 & 87.40 & $<0.00001$ \\
\hline Ptilophyllum sp. & 1.5 & 2 & 0.15892 & 12 & 15.70 & 0.00009 \\
\hline Zamites schmiedelii & 8.9 & 15.4 & 0.00011 & 74.7 & 130.0 & $<0.00001$ \\
\hline
\end{tabular}

Table 1 Stepwise selection of response variables in three groups of species discriminated in PCA analysis, according to logistic regression model with logit link function and binomial response assumed. $\mathrm{R}^{2}$ - coefficient of determination, $\mathrm{F}-\mathrm{a}$ partial $\mathrm{F}$ test, $\mathrm{p}-\mathrm{I}$ type error. 


\begin{tabular}{|c|c|c|c|}
\hline taxon & $\begin{array}{l}\text { group } \\
\text { number }\end{array}$ & $\begin{array}{l}\text { sedimentary } \\
\text { environment } \\
\text { (Anina) }\end{array}$ & Proxies for environmental requirements \\
\hline $\begin{array}{l}\text { Nilssonia sp. } 1 \\
\text { with entire margin }\end{array}$ & 1 & $\begin{array}{l}\text { Finely laminated } \\
\text { sandstones and } \\
\text { paleosoils }\end{array}$ & $\begin{array}{l}\text { upland forest or moist lush (depending on species) } \\
\text { (van Konijnenburg-van Cittert \& van der Burgh, } \\
1996 \text { p. 8.). } \\
\text { Moderately disturbed, relatively dry to moderately } \\
\text { wet (non-flooded) inland areas (Barbacka, 2011) }\end{array}$ \\
\hline $\begin{array}{l}\text { Podozamites } \\
\text { paucinervis }\end{array}$ & 2 & $\begin{array}{l}\text { Roof shales and fine } \\
\text { sandstones }\end{array}$ & mire borders in flooded areas (Popa, 1997) \\
\hline $\begin{array}{l}\text { Cladophlebis } \\
\text { nebbensis }\end{array}$ & 2 & $\begin{array}{l}\text { Paleosoils and roof } \\
\text { shales }\end{array}$ & $\begin{array}{l}\text { Schweitzer et al. (1997), Popa }(1997,1998) \\
\text { Floodplain areas }\end{array}$ \\
\hline $\begin{array}{l}\text { Dictyophyllum } \\
\text { nilssonii }\end{array}$ & 2 & $\begin{array}{l}\text { Paleosoils and roof } \\
\text { shales }\end{array}$ & $\begin{array}{l}\text { Weakly disturbed, moderately wet canopy } \\
\text { (Barbacka, 2011) } \\
\text { moist marsh (van Konijnenburg-van Cittert, 2002) }\end{array}$ \\
\hline $\begin{array}{l}\text { Neocalamites } \\
\text { (Schizoneura) } \\
\text { carcinoides }\end{array}$ & 2 & Roof shales & $\begin{array}{l}\text { Weakly disturbed, moderately wet canopy } \\
\text { (Barbacka, 2011) } \\
\text { marsh (van Konijnenburg-van Cittert 2002) }\end{array}$ \\
\hline Ginkgoites sp. & 3 & $\begin{array}{l}\text { Roof shales and } \\
\text { paleosoils }\end{array}$ & $\begin{array}{l}\text { Coastal, warm, humid (Harris, 1937,1961, 1964, } \\
\text { 1969; Harris \& Millington, 1974), } \\
\text { stable and ecologically saturated (Zhou, 2009) } \\
\text { wetland (Abbink et al., 2004) } \\
\text { stable wetland (Francis et al., 2008) } \\
\text { wet (Hesselbo et al., 2003) } \\
\text { upland (Popa \& van Konijnenburg-van Cittert, } \\
\text { 2006) }\end{array}$ \\
\hline $\begin{array}{l}\text { Cladophlebis } \\
\text { denticulata }\end{array}$ & 3 & $\begin{array}{l}\text { Roof shales and } \\
\text { paleosoils }\end{array}$ & $\begin{array}{l}\text { Highly disturbed short-lived, moderately } \\
\text { wet territories formed by alluvial deposits } \\
\text { (islands, peninsulas, forelands), fully damaged } \\
\text { by river flood, occupied by coloniser plants } \\
\text { (Barbacka, 2011) } \\
\text { riverbanks, or in freshwater } \\
\text { marshes (van Konijnenburg-van Cittert, 2002) } \\
\text { floodplains and lowlands (Gordenko, 2008) }\end{array}$ \\
\hline Zamites schmidelii & 3 & Roof shales & $\begin{array}{l}\text { flood plains or levees (Givulescu, 1998; Popa, } \\
\text { 1998, 2014) }\end{array}$ \\
\hline
\end{tabular}

Table 2 Environmental requirements of the most important species forming ecogroups in Anina. 